\title{
Sound and Stylistic Meaning in Helon Habila's Measuring Time
}

\author{
Ebi Yeibo \\ Department of English and Literary Studies, Faculty of Arts, Niger Delta University, Wilberforce Island, Bayelsa State, \\ Nigeria \\ Email: eyeibo@gmail.com \\ Tamunotonye Alabrabra \\ Department of English Studies, Faculty of Humanities, University of Port Harcourt, Port Harcourt, Rivers State, Nigeria. \\ Email: lovelytonyein@yahoo.com
}

\begin{abstract}
Earlier reviews of Helon Habila's Measuring Time concentrated on literary features, such as theme, plot, characterization and subject matter in the text. However, such reviews have paid little attention to the role sound devices play in foregrounding stylistic meaning, which is very crucial for a comprehensive description and interpretation of the text. This study, therefore, applies the insights and techniques of general linguistics to investigate the stylistic value of phonological devices as semantic signifiers or reinforcers in the text. Specifically, the study deploys M.A.K. Halliday's three metafunctions of language viz: ideational, interpersonal and textual, as the analytical model, to examine the use of sound devices such as parallelism, repetition, alliteration, assonance and onomatopoeia, to foreground aspects of meaning in the text. The study posits that, as a level of language study, phonological structure plays a fundamental role in encoding the meaning and aesthetics of Helon Habila's text, and literary discourse in general.
\end{abstract}

Index Terms - sound devices, stylistic meaning, Helon Habila, Measuring Time

\section{INTRODUCTION}

Every individual has his peculiar ways(s) of doing things. Style is the term used to capture this inherent human phenomenon, which is also applicable to one's distinctive mode of expression, both orally and in writing. The style of a writer (also known as 'idiolect') is, thus, his unique way or pattern of communicating his views, feelings or messages. Babajide(2000) observes that a person's style is informed and shaped by the aggregate of his social and political background, religious inclination, cultural values, experience, educational attainment, geographical location, and exposure (p.125).

From the foregoing, it is crystal clear that language is not only a means of communication; it is also critical for literary creativity and production. This view is corroborated by Yule's (1996) thesis that language can be used to bring into existence, by applying the imagination in some artistic technique. Todorov (1977) echoes the same idea when he posited that literature has language as both its point of departure and its destination; language furnishes literature its abstract configuration. According to Dada (2004),

Literature is written in language using the techniques and features of language such as tone, grammatical structure, diction and metaphor. (p.3)

This overwhelming fact justifies the examination of the language of given writer, not only to distil his distinctive style, but also to enhance the interpretation and understanding of his idiolect.

Fundamentally, however, language is a complex phenomenon with varied integral layers and constitutive levels, and elements of all these layers or levels are deployed or combined by a given author, to encode meaning and achieve aesthetic effects in his texts. Hence Alo (1998) posits that, the verbal style involves "..all the devices of language that are used to achieve communication goals in speech and writing..."(p. 1). The implication of this thesis is that the language scholar should be interested in all of these constitutive layers or levels. Dada (2004) captures this view inter alia:

A literary work is written in a language and to Understand the work fully, there must be recourse to language in all its aspects - phonetics, phonology, semantics, syntax, etc. (p. 1)

This fact explains why stylistic analysis applies the principles and techniques of general linguistics to the description and interpretation of salient graphological, phonological, syntactic, lexical and semantic features of a text, with a view to characterizing the writer's idiolect.

The present study, therefore, examines the phonological (i.e. sound) devices deployed by Helon Habila in his Measuring Time, in order to determine their semantic implications in the text. In other words, our task in this study is to determine the nexus between sound and meaning in the linguistic structure of Habila's text. 


\section{THEORETICAL FOUNDATIONS/LITERATURE REVIEW}

The concept of linguistic style in literature has been a subject of intense interest by language scholars through the ages, which has resulted in multifarious definitions and theories for its critical exploration. The Russian formalists and the Prague school of the 1920's, the structuralists of the 1960's and Noam Chomsky's (1957) Transformational generative grammar, for instance, have all explained and approached the concept from their distinct perspectives. However, since this study focuses on a functional use of language, we shall adopt M. A. K. Halliday's systemic functional grammar as the theoretical model for the analysis. The interest of this grammar is not only in describing the structure of language, but also in explaining the properties of discourse and its functions. It revolves around the work of J.R. Firth in general and M.A.K. Halliday in particular. In Hallidayan (1971) perception, a formal feature is stylistic if it has a particular meaning, effect or value. This notion emphasizes how language functions in texts and the nexus between language and what it is used for, or to achieve. The critical point here is that, whatever linguistic resource that is worth describing must be put to use, in the sense that the description and interpretation are necessarily based on the situational variables that prompted its use. Hence Oha (1994) posits that the approach recognizes the interdependency of style, meaning and context of situation and that the latter should not be subjected to second fiddle position, or ignored, in the analysis of style (p. 730).

In Systemic Functional Grammar, language structure is analyzed along semantic, phonological, lexical and grammatical lines. Language function, on the other hand, is examined from three angles viz: ideational, interpersonal and textual. These are referred to as the metafunctions of language. The ideational metafunction of language is synonymous with the field of discourse i.e. the subject matter or propositional content of the text and the context of language use i.e. is it a religious or socio-political subject? According to Adeyanju (2008), it “...implies that language serves as an instrument for the encoder (speaker, writer) to express and articulate his idea and experience internally"(p.86). The interpersonal or interactional function, at another level, refers to the tenor of discourse i.e. the social relationship that exists among participants in a specific discourse situation, which can influence or shape language use. According to Ogunsiji (2001), it “... helps to establish and sustain social relations" (p.77).

The textual aspect is particularly germane to the present study. It is concerned with the mode; the internal organization and communicative nature of a text. Leech and Short (1985) see Halliday's textual functions of language as “...ways of using language to organize, understand and express information for effective communication"(p. 209). In Adeyanju's (2008) view, it suggests “... the availability of an internal structure which makes it possible for the writer or speaker to construct texts that are not only coherent but also situationally appropriate"(p.87). The main point is that, the textual metafunction relates what is said in a text to ideas outside the discourse, as we shall demonstrate in the present study.

Habila's place in the third generation of Nigerian prose fiction writers is assured, both by his manifest artistic talent and the wide critical acclaim his works have attracted. In fact, Measuring Time has been a subject of world-Wide reviews in many reputable organizations like the Daily Mail of London, Library Journal of U.S.A. The London Observer, The Guardian of London, O. Magazine and The Booklist of U.S.A. However, from available literature, it has not been examined from critical linguistic perspectives, as most of the reviews have approached the work from the literary angles of theme, plot, characterization, subject matter, etc, exploring socio-historical, economic, psychological and political issues, as encapsulated in the text. For instance, Foden (2007) sees the text as a study in historical periods, man's psychology and relativism; Flanagan (2007) focuses on the text's exposition of African village life and politics, and the artistic skill, discipline and maturity evident in the narratology; while Kunzru (2007) examines the work's plot and the theme of struggle in a decadent and cynical world. The present study, therefore, seeks to fill this gap by foregrounding the role phonological devices play in encoding the meaning and aesthetics of the text.

\section{The CONCEPTS OF SOUND AND STYLISTIC MEANING}

Language is usually studied at different levels viz: phonology (sound), syntax (sentence structure) semantics, (meaning), morphology (internal structure of words), lexis (words). It is a semiotic system in the sense that it operates on conventional symbols and sounds which help inhabitants of a particular speech community to communicate. Communication itself takes place because these symbols and signs are meaningful i.e messages are associated with or attached to them.

In literary production, writers exploit or manipulate the resources of language to encode meaning, transmit messages and achieve aesthetic effects, in given textual situations. As we have earlier stated, the peculiar way a writer goes about this enterprise constitutes his style. Hence Halliday (1978) contends that style is language in use in relation to the various levels of meaning contained in a work of art.

Essentially sound is one of the linguistic elements exploited by writers to encode meaning. Basically there are two forms of human communication capable of producing meaning viz: Speech (Spoken) and writing (Written). The written form uses graphic symbols while the spoken form uses speech sounds. The airstream from the lungs provides the energy used in the production of human speech sounds which are basically vowels and consonants. According to Ufomata (1996), 
The human vocal organs are made to be able to produce an enormous number of these sounds, but each language selects only a few, which it then puts together, not in an arbitrary manner, but also according to a number of specific rules. (p.191)

In the English language i.e. Received Pronunciation (RP), there are twenty (20) vowel sounds and twenty-four (24) consonants, resulting in forty-four (44) phonemes. Vowel sounds are further broken down into monophthongs (12) and diphthongs (8). The critical point is that, as we shall demonstrate in our textual analysis, sound devices such as assonance, alliteration, onomatopoeia, syllable structure, parallelism, repetition etc, are usually deployed by writers for the creative enterprise. Alo (1998) explains that:

Every word in a language has its phonetic substance, vibration and quality. Each sound behaves in a certain way; some jar the ear; others soothe. The creative language user exploits the inherent qualities in speech sounds in his word choices... to produce special effect.

On the other hand, meaning is at the centre of language use i.e. every linguistic exercise aims to impart meaning. Thus various theories and approaches have been propounded by language scholars to explicate the concept viz: referential, image, ideational, behavioural and contextual theories of meaning. Stylistic meaning is one of the seven types of meaning identified by Leech (1974), others being conceptual or denotative, connotative, collocative, reflected, affective and thematic meaning. Ogunsij (2000) posits that it is considered "..... in relation to the situation in which an utterance is made"(p.53). This means that stylistic meaning refers to meanings that are shaped or conditioned by contextual variables or the environment of use. According to Ogunsiji (2000) these variables or factors include: geographical location, subject matter, medium (spoken or written), sex, age, role relationships etc. Therefore, as we have earlier stated, the present study seeks to bring out the combination of sounds that produces distinctive meanings and aesthetic effects in Helon Habila's text, by applying the principles of general linguistics.

\section{BRIEF BIOGRAPHY OF THE AUTHOR}

Helon Habila was born 1967 in Kaltungo, Gombe State of Nigeria and educated at the University of Jos, Nigeria and the University of East Anglia, England. He teaches creative writing at the George Mason University in Fairfax, Virginia in the U. S. A. where he lives with his family.

Habila is a young writer whose first book Waiting for an Angel was awarded the Commonwealth Writers prize for new writing (African region 2003) and the Caine Prize (2001). In 2002, he won the Muson Poetry Prize in Nigeria. He was the first Chinua Achebe Fellow at Bard College (2005), a William B. Quarton Fellow at the University of Iowa International Writing programme and the John Farrar Fellow in Fiction at the 2003 Bread Loaf Writers. He co-edited the British Council's New Writing 14 with Lavinia Greenlaw.

\section{SynOPSIS OF THE TEXT}

It is expedient to summarize the content of the text since language use is based on it. In other words, our analysis of the language of Measuring Time would relate essentially to the content which forms the social and cultural ambience of the text.

Measuring Time is a novel that tell us the story of the twin brothers Mamo and La Mamo whose mother dies as they are born into the world. They grow up with their father, Lamang in a small village in Northern Nigeria called Keti. The hatred they have for their father because of his behaviour towards them and stories heard from gossips, make them take a decision to run away in order to join the army and become solders. Mamo who is suffering from sickle cell anaemia, falls sick on the way and is forced to stay behind while his brother LaMamo goes ahead to become a soldier. Mamo decides to go to school in order to fight the sickness and he becomes a teacher in history, in the village school. While he teaches, his brother is fighting in the war and sends him sketch letters regularly, about the happenings of the war.

Mamo in the village explores the local history by a white man, Drinkwater and is recruited by the traditional ruler, the Mia, to become his secretary and to write a true history of his people, due to the fame given to him by the reply of one of his articles from a British Journal. He fall in love with Zara who assists him with his article while LaMamo risks his life for a girl who would have been raped. Lamang on the other hand fights for political office and is betrayed by one of his party members.

Measuring Time also includes other minor characters like Aunty Mariana, a witch, the widows, a drunken cousin and others.

\section{TeXtual ANALYSIS}

It is expedient to establish that our analysis of phonological devices in the text is based on parallelism, repetition, alliteration, assonance, and onomatopoeia, as a result of their strategic importance as elements of signification and aesthetics in the text.

\section{A. Parallelism}

According to Adeyanju (2008), parallelism could be described as “... similarity of features of successive lines of poetry”(p.91). This scholar explains that it is a characteristic of Hebrew poetry as claimed by Livingstone (1977, p.30) 
and referred to in Adeyanju (1998, p.112). It is expedient to mention, however, that parallelism applies not only to poetry texts but texts of all sorts where there is a deliberate manipulation of linguistic resources to achieve beauty and convey meaning. In Yankson's (1987) view, this rhetorical structural pattern or device deals with the phonetic bond that exists between two or more lexical items in a text, which have a paradigmatic or syntagmatic relationship. Yankson (1987) contends that "one of the stylistic effects of linguistic parallelism is to invest lexical items with the same value ... the three levels of linguistic organization - syntactic, semantic and phonetic - converging on and reinforcing each other"(p. 50). In Habila's Measuring Time, it is repeatedly used, in the sense that the author uses the syntactic and phonological mode of expression to show parallelism in the novel. A good example is the use of the words "slimmer" and "thinner"(p.262). Semantically, the lexical items 'slimmer' and 'thinner' are related synonymously, having the same feature adverbial/+size/. Both words also share the same final sound / $\partial$ and the same stress pattern or stress isochronicity of two syllables, 'thin'ner 'slim'mer'. This is a case of syntactic, phonological and semantic parallelism. The stylistic effect of such parallelism is to invest the given items with the same value i.e. intra-textually, the items 'thinner' and 'slimmer' are the same in structure and sense. Other instances in the text include the following:

Yawning and blinking.... (p.256)

Verb/+ action/, / /, two syllables

Contractors and councilors.... (p251)

Noun/+persons/, / $2 /$, three syllables

Running and screaming, slashing...(P184)

Verb/+ action, /y /, two syllables

The critical point is that Habila uses repetitive structural patterns in relation to meaning, to add stylistic effects to his novel. In addition, the words used to achieve sound effect have the same stress pattern.

\section{B. Repetition}

Repetition is also a stylistic device under phonology in which parallel words are repeated in lines to draw the reader's attention to what the writer is actually saying. It is also intended to intensify meaning as well as being an aspect of a particular thesis i.e. using it in a logical way to present content as real. When some words are repeated, they add rhythmic effects to the lines in which they occur. Therefore, Habila has used this device not only to achieve realism but also as a decorative device to add beauty and aesthetic effects to the work. We shall now present some aspects of repetition from the text to illustrate our views.

The song at the beginning of the novel which the villagers composed for Lamang has a stimulating effect produced by the repetition of the words in the lines to bring out specific sounds and meanings i.e.

Mother sighing with longing

Daughter sighing with longing.... (p. 13)

The words "sighing with longing" demonstrate how much women love Lamang and are repeated to emphasize this meaning and create sound effect. Specifically, the repetition makes the lines catchy, which aligns with the meaning of love and longing that they are meant to depict. Additionally, the ...ing / $\boldsymbol{y} /$ form or structure in the two words suggests a continuum; an endless, undiminishing love. Habila has carefully repeated words in so many other lines and we would randomly look at some in the text:

She is dead, she is dead.... (p. 15)

Shot, he was shot... (p. 175)

Waited and waited ....(p. 175)

weight of grief, her grief ...(p. 187)

Walking boots and rain boots....(p. 210)

Sunk lower and lower...(P. 218)

Clever, very clever .... (P. 234)

Calm down, calm down ... (P. 254)

Money, more money ... (P. 284)

Blood, blood ... (P. 229)

In the text, the author also repeats some words and phrases in two different lines close to each other but in the same position. Let us consider the extract below:

his own village oak trees...

in the first year of trees ...(P. 225)

This is a technique of parallelism and repetition used by Habila all over the novel and it is used in all the instances and contexts highlighted above for similar reasons as we have earlier stated (i.e. to achieve realism and achieve beauty in form).

\section{Alliteration}

According to Adeyanju (2008), alliteration is the use of “... the same consonant at the beginning of nearby words"(p.91). In other words, it is the repetition of initial consonant sounds within a line of discourse. It is the use of words that begin with alphabets which have the same sounds and are relatively close in a particular line. The deployment of alliteration in a particular discourse situation is usually for aesthetic and functional purposes. In studying 
Habila's Measuring Time, we observed that the text displays alliteration all over for stylistic effect. We would analyze some of these instances for the sake of illustration:

Of the feeling of abandonment he and

his brother always felt when after waiting

for weeks for their father to return from ... (P. 183)

In the extract above, we see the way Habila alliterates the /f/ labio-dental fricative consonant. This is a strong, voiceless consonant and it can be said that the author has used it consciously to capture that aspect of meaning i.e. it suggests the strong feelings that the words are meant to express. There are other areas where the /f/ consonant is used for almost the same stylistic effect and meaning i.e.

From friends and failed to ... (P. 120)

Far away from her friends ... (P. 268)

I fell from the farm tree ... (P. 297)

On the other hand, Habila has utilized the /w/ consonant which is a weak one, for instance, to capture situations or events that are not necessarily energised. This implies that the bilabial approximant $/ \mathrm{w} /$ is used by the author to suggest that the situation or subject is not particularly passionate, impassioned or exciting as exemplified by the extract below:

When he attempted to walk on his own, even with his walking stick, his hands would shake and the stick would wobble and ... (P. 182)

The fundamental point here is that the extract suggests weakness and Habila foregrounds this semantic slant by using the /w/ consonant. Other examples from the text include:

Was like walking on water ... (P. 123)

wouldn't...want to waste ... (P. 199)

who were working with ... (P. 205)

It is expedient to mention that alliteration in Habila's text is not restricted to the fricative consonant /f/ and bilabial approximant /w/ as we have highlighted above with the illustrations. This sound device manifests in varying forms throughout the text, as exemplified below:

$/ \mathrm{s} / \ldots$ stood staring and sniffing ... (P. 119)

/s/... student, secondary school ... (P. 152)

/b/... big bed and brought ... (P. 244)

/b/ Bulbs blinked ... (P. 246)

$/ \mathrm{t} /$... twisting and torturing ... (P. 182)

$/ \mathrm{p} / \ldots$ pointing ... plane passing ... (P. 118)

$/ \mathrm{p} / \quad$ Picked up a pen and paper ... (P. 179)

$/ \mathrm{h} / \ldots$ had her head in her hands ... (P. 174)

/h/ Her hands ... her wet hair ... (P. 264)

The significant stylistic point here is that in all of these forms and contexts, it is used to foreground aspects of meaning and also to serve specific aesthetic purposes. In other words, the use of this device in the text also demonstrates how sound can be manipulated to convey stylistic meaning in a given discourse.

\section{Assonance}

Assonance deals with the repetition of identical vowel sounds where there is no full rhyme. The sounds are produced when two syllables in words that have the same vowels and different consonants are placed close together. In Adeyanju's (2008) view, it is “... the use of the same vowel sound in the middle of nearby words" (p. 97). The critical point is that Habila also uses this device to distil or bring out sounds of words which have overt stylistic meanings. He uses this device, for instance, to announce one of the sub-titles of the text, which we would analyze shortly: "Lives and times... (P. 197). These two words are used severally in the text and Habila uses them together to bring out their centrality to the meaning of the entire discourse. The critical point here is that both of them contain the loud diphthong /ai/. In other words, there is a formal correspondence between the relative loudness of the sound and the overwhelming importance of the meaning of the words to the text, as they are at the centre of the whole story. So, the loud diphthong /ai/ could be said to be emphasizing or echoing one of the main points or issues in the entire text: Lives and Times. Thus, the form used in this context is suggestive of the sense. Other instances of the use of assonance in the text include the following:

$/ \wedge / .$. flew up and cut ... (P. 145)

/^/ Come, but some ... (P. 15)

$/ \mathrm{u}: / \ldots$ two bedroom and a living room ... (P. 222)

/u:/ To loot and shoot ... (P. 138)

/i:/... huge neem trees ... (P. 78)

/i:/ With real weakness ... (P. 188)

/i/... slimmer, thinner... (P. 262)

/i/... Licking his lips ... (P. 24)

$/): / \ldots$ wạs like walking on water ... (P. 123)

/)/ Form of a foreword ... (P. 215) 
/ai/... like a sigh ... (P. 190)

/ai/...B. Bride-price ... (P. 181)

/OU/... spoke slowly almost ... (P. 184)

Importantly, in all of the foregoing instances, the author has demonstrated that vowel sounds can also be manipulated by a literary artist to foreground aspects of meaning and also create aesthetic value.

\section{E. Onomatopoeia}

Onomatopoeia is a phonological device of stylistics in which the sounds suggest the meaning of words or expressions because the words are formed by imitating the actual or natural sounds associated with the things concerned. Habila uses this device to reflect sense in the sound of words which have similar sounds to the one described. This device is used by the author to foreground meaning and also for stylistic effects, even though we agree with Leech's (1969) contention that,

...this power of suggesting natural sounds or other qualities is relatively weak - too weak to operate unsupported by meaning - and because of its range, is only latent. (See Yankson, 1987,p.54).

A typical example of Habila's exploration of this device in the text would be analyzed below:

now she was at the window; she hammered at it with her walking stick, tap-tap-tap, till gradually the glass began to crack ... (p. 27)

In this context, we see that Habila captures the sound of the glass as it is being hit with a walking stick by repeating the word "tap...tap...tap" three times. It is a device he uses to make meaning quite accessible and realistic and also to add rhythmic beauty to the work. Other examples of this device in the text include the following:

The flies buzzed joyfully ... (P. 39)

Mewing like a cat ... (P. 44)

The wood creaking ... (P. 71)

The crowd gave a roar ... (P. 148)

I am babbling ... (P. 188)

His voice becoming whispery ... (P. 208)

The crowd sent up a wail ... (P. 228)

Cock brings to crowing ... (P. 259)

Although we also agree with Yankson (1987) that "this is perhaps the most subjective area of literary appreciation", there is no doubt that this device helps the author to create a palpable sense of realism and splendour in the work (p.54). Significantly, this style seems to tally with Yankson's (1987) contention that,

Any sound features which a poet may employ to echo, suggest or enact meaning can work only in conjunction with the meaning of the poetic text. (P.54)

In other words, the suggestive power of the onomatopoeic usages in the text is realized by the textual contexts in which they appear.

\section{CONCLUSION}

In this study we have applied the insights and methods of functional linguistics to examine the role sound devices play in encoding or reinforcing meaning and achieving aesthetic effects in Helon Habila's Measuring Time. No doubt, the study demonstrates the inexorable relationship between language and literature. The plain fact is that language is the singular medium of literary communication and a given writer inevitably selects his mode of presentation or signification in a given context to catch the attention of the reader in particular ways. This implies that linguistic structure or organization is of prime importance in literary production and interpretation. Thus, Jacobson contends that, the most important feature of literature is the way structure is organized to foreground the substantive elements of texts, particularly phonology, syntax and other levels of language.

\section{REFERENCES}

[1] Adeyanju, D. (2008). "Season's Greetings from a Cleric: A Stylo-Semantic Analysis of Pastor Adebayo's 'New Year Compliments'.” In Atoye, R.O. (ed.) Papers in English and Linguistics (PEL). vol. 9, Ile-Ife: O.A.U

[2] Alabrabra, T. (2009). A Stylistic Analysis of Helon Habila's Measuring Time. An unpublished B.A. Long essay, Niger Delta University, Wilberforce Island, Bayelsa State, Nigeria.

[3] Alo, M. (1995). Applied English Linguistics: An Introduction. Port Harcourt: Aeddy link.

[4] Alo, M. (1998). Style in Language and Communication. Port Harcourt: Aeddy Link.

[5] Babajide, A.O. (2000). "Of Style and Stylistics. In A.O. Babajide (ed.) Studies in English Language. Ibadan: Enicrownfit publishers.

[6] Crystal, D. (1987). The Cambridge Encyclopedia of Language. Cambridge: C.U.P.

[7] Crystal, D. and Davy, D. (1969). Investigating English Style. London: Longman.

[8] Dada, P.O. (2004). English and Literary Stylistics. Makurdi: Abogom Press.

[9] Habila, H. (2007). Measuring Time. Norton: Cassava.

[10] Halliday, M. A.K. (1970). "Language Structure and Language Function." In New Horizons in Linguistics. Harmondsworth: Penguin Books. 
[11] Halliday, M. A.K.(1973). Explorations in the Functions of Language. London: Edward Arnold.

[12] Halliday M.A.K. (1978). Language as a Social Semiotic: The Social Interpretation of Language and Meaning. London: Edward Arnold.

[13] Leech, G.N. (1969). A Linguistic Guide to English Poetry. London: Longman

[14] Leech, N.G. and Short, M.H. (1981). Style in Fiction: A Linguistic Introduction to English Fictional Prose. London: Longman

[15] Ogunsiji, A. (2000). "Introductory Semantics." In A.O. Babajide (ed.) Studies in English Language. Ibadan: Enicrownfit Publishers.

[16] Ogunsiji, Y. (2001). “A Sociolinguistic Study of Language Attitude in Market Transaction.” In Igboanusi, H. (ed.) Language Attitude and language Conflict in West Africa. Ibadan: Enicrownfit Publishers.

[17] Roach, P. (2000). English Phonetics and Phonology. $3^{\text {rd }}$ (ed.) Cambridge: C.U.P.

[18] Todorov, T. (1977). The Poetics of Prose. New York: University Press.

[19] Ufomata, T. (1996). "Phonetics." In Longe, V.U \& Ofuani, O.A.(eds.) English Language and Communication. Benin-City: NERA.

[20] Wellek, R. and Warren, A. (1977). The Language of Literature. London: Longman.

[21] Yankson, K. E. (1987). An Introduction to Literary Stylistics. Obasi: Pacific.

[22] Yule, G. (1996). The Study of Language. $2^{\text {nd }}$ ed. Cambridge: C.U.P.

[23] Yeibo, E. (2011). "Patterns of Lexical Choices and Stylistic Function in J.P. Clark-Bekederemo's Poetry". In Ahmadi, A. (ed.) International Journal of English Linguistics. Toronto: Canadian Center of Science and Education.

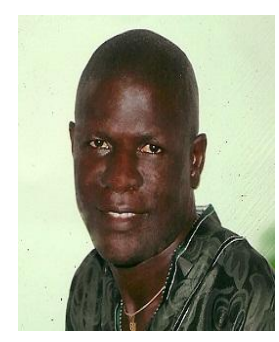

Ebi Yeibo was born in Bomadi, Delta State, Nigeria, on February 24, 1969. He obtained degrees in English from the Delta State University, Abraka (1996) and the University of Ibadan (2000), Nigeria, specializing in discourse analysis and stylistics.

He teaches stylistics, discourse analysis, applied linguistics, semantics and history of the English language at the Niger Delta University, Wilberforce Island, Bayelsa State, Nigeria, and has published scholarly papers on these areas in local and international journals. An award-winning poet, his published volumes of poetry include: Maiden Lines (Ibadan: Akol Press, 1997), A Song for Tomorrow (Ibadan: Kraftbooks Ltd, 2003), and The Forbidden Tongue (Ibadan: Kraftbooks Ltd, 2007).

Mr. Yeibo is a member of various professional and learned associations in Nigeria: Association of Nigerian Authors (ANA), Linguistics Association of Nigeria (LAN), and Nigerian Institute of Public Relations (NIPR).

Tamunotonye Alabrabra was born May 30, 1987, in Port-Harcourt, Rivers State, Nigeria. She obtained a degree in English and Literary Studies from the Niger Delta University, Wilberforce Island, Bayelsa State, Nigeria and is, at present, an M.A. Student in the Department of English Studies, University of Port-Harcourt, Nigeria. 